\title{
Model Pembelajaran Berbasis Discovery- Inkuiri dan Kontribusinya Terhadap Penguatan Kualitas Pembelajaran di Sekolah Dasar
}

\author{
Maruslin Sirait \\ Sekolah Dasar Negeri 117 Rejang Lebong \\ maruslin.sirait@gmail.com
}

\begin{abstract}
A convensional teaching models and monotonous that often happen in teaching process needs to behave seriously by the stakeholder that there are in makro and mikro levels, especially for the teacher that in touch directly in teaching process. teachers need to realize that basically the students have learning variation that we cant make it in the same way. Learning models that should be understood by the teachers in doing learning to create a masterpiece learning process that can change learning situation from passive become active and reactive for the students.
\end{abstract}

Keywords: Learning Models, Discovery, Inkuiri.

\begin{abstract}
Abstrak : Model pembelajaran konvensional dan monoton yang masih sering terjadi dalam proses pembelajaran perlu disikapi secara serius oleh para stakeholder yang berada di level makro maupun mikro, khususnya pendidik yang terlibat langsung dalam kegiatan pembelajaran. Seyogyanya kalangan pendidik menyadari bahwa pada dasarnya peserta didik memiliki beragam cara belajar yang tidak bisa kita anggap sama rata. Model pembelajaran Discovery-Inkuiri merupakan salah satu dari beberapa model pembelajaran yang patut dipahami para pendidik dalam melaksanakan pembelajaran dalam rangka menciptakan maha karya proses pembelajaran yang dapat mengubah suasana pembelajaran dari pasif menjadi aktif dan kreatif bagi peserta didik.
\end{abstract}

Kata Kunci: Model Pembelajaran, Discovery, Inkuiri

\section{PENDAHULUAN}

Penyelenggaraan sistem pendidikan di Indonesia pada umumnya lebih mengarah pada model pembelajaran yang dilakukan secara massal dan klasikal dengan berorientasi pada kuantitas agar mampu melayani sebanyak-banyaknya peserta didik sehingga tidak dapat mengakomodasi kebutuhan peserta didik secara individual di luar kelompok. Pendidikan hendaknya mampu mengembangkan potensi kecerdasan serta bakat yang dimilikinya menjadi suatu

AR-RIAYAH : Jurnal Pendidikan Dasar vol.1, no. 2, 2017

STAIN Curup - Bengkulu | p ISSN 2580-362X; e ISSN 2580-3611

http://journal.staincurup.ac.id/index.php/arriayah 
prestasi yang punya nilai jual. Sistem pendidikan di Indonesia harus di fokuskan pada keberhasilan peserta didik dengan jaminan kemampuan yang diarahkan pada life skill yang dikemudian hari dapat menopang kesejahteraan peserta didik itu sendiri untuk keluarganya serta masa depannya dengan kehidupan layak di masyarakat. ${ }^{1}$

Pendidikan merupakan bagian yang sangat penting bagi kehidupan manusia untuk mengaktualisasikan potensi mereka dalam menjalankan tugasnya sebagai khalifah di permukaan bumi. Hal ini tergambar sekaligus membuktikan betapa urgennya pendidikan itu sendiri pada berbagai definisi berikut ini. Ensiklopedy World tertulis the education is the development of knowledge, skill, ability and character and by teaching, training, study or experience. ${ }^{2}$ Pendidikan dalam arti yang luas meliputi segala sesuatu perbuatan dan usaha dari generasi untuk mengalihkan pengetahuan, pengalaman, kecakapan serta keterampilannya kepada generasi muda sebagai usaha menyiapkannya agar dapat memenuhi fungsi hidupnya baik jasmaniah maupun rohaniah. ${ }^{3}$

Pendidikan mempunyai pengaruh yang dinamis dalam kehidupan manusia di masa depan. Pendidikan dapat mengembangkan berbagai potensi yang dimilikinya secara optimal, yaitu pengembangan potensi individu yang setinggitingginya dalam aspek fisik, intelektual, emosional, sosial dan spiritual, sesuai dengan tahap perkembangan serta karakteristik lingkungan fisik dan lingkungan sosioal budaya di mana dia hidup. Pendidikan merupakan fenomena manusia yang sangat kompleks. Pendidikan mempunyai peran yang sangat penting dalam upaya meningkatkan kualitas sumber daya manusia dan upaya mewujudkan citacita bangsa Indonesia dalam mewujudkan kesejahteraan umum dan mencerdaskan kehidupan bangsa. Pemerintah merumuskan dalam UndangUndang Republik Indonesia No 20 tahun 2003 tentang Sistem Pendidikan Nasional yang menjelaskan bahwa pendidikan dilakukan agar mendapatkan tujuan yang diharapkan bersama yaitu:

"Pendidikan membentuk watak serta peradaban bangsa yang bermartabat dalam rangka mencerdaskan kehidupan bangsa, bertujuan untuk berkembangnya potensi peserta didik agar menjadi manusia yang beriman dan bertakwa kepada Tuhan Yang Maha Esa, berakhlak mulia,

\footnotetext{
${ }^{1}$ Aris Shoimin, 68 Model Pembelajaran Inovatif dalam Kurikulum 2013, (Yogyakarta: Ar-Ruzz Media, 2016), 5

${ }^{2}$ John T. Gillespie and Christine B. Gilbert, The New Book Of Knowledge, (Grolier: Incorporated Danbury. Conn. Tth), 670.

${ }^{3}$ Poerbakawatja Soegarda, Ensiklopedi pendidikan, (Jakarta : Gunung Agung,1976), 214.
} 
sehat, berilmu, cakap, kreatif, mandiri, dan menjadi warga negara yang demokratis serta bertanggung jawab" (Pasal 3 UU RI No 20/ 2003). ${ }^{4}$

Pembelajaran merupakan suatu proses yang dilakukan secara sadar pada setiap individu atau kelompok untuk merubah sikap dari tidak tahu menjadi tahu sepanjang hidupnya. Sedangkan proses belajar mengajar merupakan kegiatan pokok sekolah yang di dalamnya terjadi proses siswa belajar dan guru mengajar dalam konteks interaktif dan terjadi interaksi edukatif antara guru dan siswa, sehingga terdapat perubahan dalam diri siswa baik perubahan pada tingkat pengetahuan, pemahaman dan keterampilan ataupun sikap. Melalui proses mengajar tersebut akan dicapai tujuan pendidikan tidak hanya dalam hal membentuk perubahan tingkah laku dalam diri siswa, akan tetapi juga meningkatkan pengetahuan yang ada dalam diri siswa.

Model pembelajaran memiliki urgensi tinggi dalam pengorganisasian proses pembelajaran di dalam kelas secara aktif. Pembelajaran aktif menjadi strategi yang paling popular dalam dunia pembelajaran kekinian. Asumsi yang digunakan dalam pembelajaran aktif adalah siswa menjadi subyek belajar, sedangkan guru diposisikan sebagai pendamping, pengarah atau fasilitator. Hampir semua praktisi pendidikan percaya bahwa pembelajaran aktif akan menghasilkan output sekaligus peserta didik yang kreatif dan mampu menjawab persoalan-persoalan yang dihadapinya di dunia nyata. Selain itu, masa depan peserta didik menjadi tidak perlu ditakutkan lagi dikarenakan mereka sudah mampu mengelola secara aktif potensi mereka masing-masing.

Model pembelajaran merupakan pola yang digunakan sebagai pedoman dalam merencanakan pembelajaran di kelas maupun tutorial. Model pembelajaran dapat didefinisikan sebagai kerangka konseptual yang melukiskan prosedur sistematis dalam mengorganisasikan pengalaman belajar untuk mencapai tujuan belajar. ${ }^{5}$ Hamruni mendefinisikan model pembelajaran sebagai bentuk pembelajaran yang tergambar dari awal sampai akhir yang disajikan khas oleh guru. ${ }^{6}$

Selanjutnya, model akan dapat diposisikan secara jelas jika dikaitkan dengan istilah pendekatan, strategi, metode, dan teknik. Pendekatan merupakan

\footnotetext{
${ }^{4}$ Undang-Undang RI No. 20 Tahun 2003, Sistem Pendidikan Nasional, (Jakarta: Citra Umbara, 2003), 7.

${ }^{5}$ Agus Suprijono, Cooperative Learning: Teori dan Aplikasi PAIKEM, (Yogyakarta: Pustaka Pelajar, 2013), 45.

${ }^{6}$ Hamruni, Strategi dan Model-Model Pembelajaran Aktif yang Menyenangkan", (Yogyakarta: Fakultas Tarbiyah UIN Sunan Kalijaga Yogyakarta, 2009), 5.
} 
sudut pandang kita terhadap proses pembelajaran. Strategi merupakan rancangan atau rencana pembelajaran yang menyangkut semua hal terkait dengan pembelajaran. Metode merupakan cara yang dilakukan untuk mengimplementasikan rencana. Sedangkan teknik merupakan gaya atau style khas yang dilakukan guru dalam menjalankan metode. ${ }^{7}$

\section{KAJIAN PUSTAKA}

\section{Model Pembelajaran Discovery}

Pembelajaran discovery merupakan suatu proses dimana siswa berinteraksi dengan lingkungannya dan memperoleh informasi bagi diri mereka sendiri dengan menelusuri dan memanipulasi objek atau dengan melakukan percobaan laboratorium yang sistematis. Siswa terkadang mengingat dan mentransfer informasi secara lebih efektif ketika mereka mengkonstruksinya sendiri ketimbang hanya membacanya atau mendengarnya.

\section{Konsep Dasar Pembelajaran Berbasis Discovery}

Jerom S. Bruner mengembangkan belajar penemuan (discovery learning) yang berdasarkan kepada pandangan kognitif tentang pembelajaran dan prinsipprinsip konstruktivis. Menurutnya, "belajar merupakan suatu proses aktif yang memungkinkan manusia untuk menemukan hal-hal baru diluar informasi yang diberikan kepada dirinya". ${ }^{8}$ Sedangkan menurut Ruseffendi metode discovery learning adalah "metode mengajar yang mengatur pengajaran sedemikian rupa sehingga anak memperoleh pengetahuan yang sebelumnya belum diketahuinya tanpa pemberitahuan langsung; sebagian atau keseluruhnya ditemukan sendiri".

Pembelajaran Discovery merupakan "cara untuk menyampaikan ide atau gagasan lewat penemuan". Kata penemuan sebagai model mengajar merupakan penemuan yang dilakukan oleh siswa, siswa menemukan sendiri sesuatu hal yang baru, ini tidak berarti yang ditemukannya benar-benar baru, sebab sudah diketahui orang lain.

Menurut Sund dalam Roestiyah, "Discovery" adalah proses mental dimana siswa mengasimilasi suatu konsep atau prinsip. Proses mental yang dimaksud adalah mengamati, menggolong, membuat dugaan, menjelaskan, mengukur,

\footnotetext{
${ }^{7}$ Hamruni, Strategi dan Model-Model.., 7.

8 Departermen Pendidikan Nasional, Teori-Teori Belajar, (Yogyakarta: Bahan Pelatihan Terintegrasi Berbasis Kompetensi Guru SMP, 2004), 8.

${ }^{9}$ Ruseffendi, Metode Penelitian, (Yogyakarta: Pustaka Pelajar, 2006), 329.
} 
membuat kesimpulan dan sebagainya. Dalam teknik ini siswa dibiarkan menemukan sendiri atau mengalami proses mental itu sendiri, guru hanya membimbing dan memberikan instruksi. Guru menjadi teman belajar, terutama dalam situasi penemuan yang jawabanya belum diketahui. ${ }^{10}$

Richard dan asistennya mencoba self-learning (belajar sendiri) itu, sehingga situasi belajar mengajar berpindah dari situasi teacher dominated learning menjadi situasi student dominated learning. Dengan menggunakan discovery learning ini, merupakan cara mengajar yang melibatkan siswa dalam proses kegiatan mental melalui tukar pendapat, dengan diskusi, seminar, membaca sendiri dan mencoba sendiri, agar anak dapat belajar sendiri. Secara sederhana, metode Discovery dapat diartikan sebagai cara penyajian pembelajaran yang memberikan kesempatan kepada peserta didik untuk menemukan informasi dengan atau tanpa bantuan guru. ${ }^{11}$

\section{Langkah-langkah Pembelajaran Discovery}

Langkah-langkah yang harus ditempuh dalam melaksanakan Model pembelajaran Discovery menurut Syaiful yaitu:

a. Perumusan masalah untuk dipecahkan siswa. Perumusan masalah untuk dipecahkan siswa merupakan kegiatan belajar yang dilakukan guru dengan memberikan pertanyaan yang merangsang berfikir siswa mengarah pada persiapan pemecahan masalah;

b. Menetapkan jawaban sementara atau lebih dikenal dengan istilah hipotesis yaitu siswa menetapkan hipotesis atau praduga jawaban untuk dikaji lebih lanjut (alternatif jawaban);

c. Siswa mencari informasi, data, fakta yang diperlukan untuk menjawab permasalahan/ hipotesis. Secara spontan siswa menjelajahi informasi atau data untuk menguji praduga baik secara individu ataupun secara kelompok melalui kegiatan;

d. Menarik kesimpulan jawaban atau generalisasi. Menarik kesimpulan yaitu siswa menarik kesimpulan jawaban melalui informasi yang diperoleh melalui kegiatan;

e. Mengaplikasikan kesimpulan/generalisasi dalam situasi baru. Mengaplikasikan kesimpulan atau generalisasi merupakan penyajian hasil kesimpulan jawaban yang diperoleh melalui

${ }^{10}$ Rostiyah, Strategi Belajar Mengajar,cet-7 (Jakarta: Rineka Cipta, 2008), 20.

${ }^{11}$ Usman, Upaya Mengoptimalisasi Kegiatan Belajar Mengajar, (Bandung: Remaja Rosda Karya, 1993), 25. 
kegiatan oleh wakil setiap kelompok melalui praktek didepan kelas. ${ }^{12}$

\section{Kelebihan Model Pembelajaran Disvovery}

a. Membantu siswa mengembangkan memperbanyak kesiapan, serta pengusaan keterampilan dalam proses kognitif pengenalan siswa;

b. Siswa memperoleh pengetahuan yang bersifat sangat pribadi individual sehingga dapat kokoh mendalam tertinggal dalam jiwa siswa tersebut;

c. Dapat meningkatkan kegairahan belajar siswa;

d. Teknik ini dapat memberikan kesempatan kepada siswa untuk dapat berkembang dan maju sesuai dengan kemampuanya masing-masing;

e. Mampu mengarahkan cara siswa belajar sehingga memiliki motivasi belajar yang sangat kuat dan giat;

f. Membantu siswa untuk memperkuat dan menambah kepercayaan pada diri sendiri dengan proses penemuan sendiri;

g. Strategi ini lebih berpusat kepada siswa tidak pada guru, guru sebagai teman dalam belajar saja atau dengan kata lain guru hanya terlibat sebagai fasilitator dalam pembelajaran membantu apabila diperlukan. ${ }^{13}$

\section{Kekurangan Model Pembelajaran Discovery}

a. Pada siswa harus ada kesiapan dan kematangan mental untuk cara belajar ini siswa harus berani dan berkeinginan dan mengetahui keadaan sekitar dengan baik;

b. Bila kelas terlalu besar penggunaan tehnik ini akan kurang berhasil;

c. Bagi guru dan siswa yang sudah biasa dengan perencanaan dan pengajaran tradisional mungkin akan sangat kecewa bila diganti dengan teknik penemuan;

d. Dengan teknik ini ada yang berpendapat bahwa proses mental ini terlalu mementingka proses pengertian saja,

${ }^{12}$ Syaiful, Strategi Belajar Mengajar, (Jakarta: Rineka Cipta, 2003),197. Berbeda dengan A. Tabrani Rusyan yang mengungkapkan tahapan penerapan belajar Discovery sebagai berikut, yaitu: 1) Stimulus (Pemberian Rangsang), 2) Problem Statement (Mengidentifikasi Masalah), 3) Data Collection (Pengumpulan Data), 4) Data Prosessing (Penggolongan Data), 5) Verifikasi, 6) Generalisasi. A. Tabrani Rusyan dkk., Pendekatan dalam Proses Belajar Mengajar, (Bandung: PT. Remaja Rosdakarya, 1994), 177.

${ }^{13}$ Suryobroto, Proses Belajar Mengajar, (Bandung: Remaja Rosdakarya, 2002), 66 
kurang memperhatikan perkembangan pembentukan sikap dan keterampilan bagi siswa;

e. Teknik ini mungkin tidak memberikan kesempatan untuk berfikir kreatif. ${ }^{14}$

\section{Model Pembelajaran Inkuiri}

Model pembelajaran ini menekankan kepada proses mencari dan menemukan. Materi tidak diberikan secara langsung, peran siswa dalam model ini yakni guru akan berperan sebagai fasilitator dan pembimbing dalam proses pembelajaran. Rangkaian kegiatan pembelajaran akan menekankan pada proses berpikir kritis dan analitis untuk mencari dan menemukan sendiri jawaban dari masalah yang dipertanyakan.

\section{Konsep Dasar Pembelajaran Inkuiri}

Inkuiri berasal dari kata to Inquire yang berarti ikut serta, atau terlibat, dalam mengajukan pertanyaan-pertanyaan, mencari informasi, dan melakukan penyelidikan. Selanjutnya Mulyono berpandangan bahwa model pembelajaran ini sering juga dinamakan strategi heuristic, yang berasal dari bahasa Yunani, yaitu beuriskein yang berarti saya menemukan. Lebih lanjut ia mengatakan bahwa strategi ini menekankan pada proses mencari dan menemukan, sehingga materi pelajaran tidak diberikan secara langsung. Peran peserta didik dalam strategi ini adalah mencari dan menemukan sendiri materi pelajaran, sedangkan guru berperan sebagai fasilitator dan pembimbing peserta didik untuk belajar. ${ }^{15}$

Pembelajaran inkuiri ini merupakan rangkaian kegiatan pembelajaran yang menekankan pada proses bepikir kritis dan analitis untuk mencari dan menemukan sendiri jawaban dari suatu masalah yang dipertanyakan. Proses berpikir kritis itu sendiri biasanya dilakukan melalui tanya jawab antara guru dan peserta didik. ${ }^{16}$

Strategi pembelajaran inkuiri banyak dipengaruhi oleh aliran belajar kognitif. Dimana menurut aliran ini, belajar pada hakikatnya adalah proses mental dan proses berpikir dengan memanfaatkan segala potensi yang dimiliki setiap individu secara optimal. Belajar lebih dari sekedar proses menghafal dan menumpuk ilmu pengetahuan, tetapi bagaimana pengetahuan yang diperolehnya

\footnotetext{
${ }^{14}$ Rostiyah, Strategi Belajar Mengajar..., 21.

15 Mulyono, Strategi Pembelajaran; Menuju Efektivitas Pembelajaran di Abad
} Global, (Malang : UIN-Maliki Press, 2011), 71.

${ }^{16}$ Mulyono, Strategi Pembelajaran..., 73. 
bermakna untuk siswa melalui keterampilan berpikir. Aliran kognitif selanjutnya melahirkan berbagai teori belajar, seperti teori belajar gestalt, teori medan, dan teori belajar konstruktivistik. ${ }^{17}$

\section{Langkah-langkah Pembelajaran Inkuiri}

Secara umum proses pembelajaran inkuiri adalah mengikuti langkahlangkah sebagai berikut: ${ }^{18}$

\section{a. Orientasi}

Langkah orientasi adalah langkah untuk membina suasana atau iklim pembelajaran yang responsif. Pada langkah ini guru mengkondisikan agar siswa siap melaksanakan proses pembelajaran. Guru merangsang dan mengajak siswa untuk berpikir memecahkan masalah. Langkah orientasi merupakan langkah yang sangat penting. Keberhasilan strategi ini sangat tergantung pada kemauan siswa untuk beraktivitas menggunakan kemampuannya dalam memecahkan masalah, tanpa kemauan dan kemampuan itu tak mungkin proses pembelajaran akan berjalan dengan lancar.

b. Merumuskan Masalah

Merumuskan masalah merupakan langkah membawa siswa pada suatu persoalan yang mengandung teka-teki. Persoalan yang disajikan adalah persoalan yang menantang siswa untuk berpikir memecahkan teka-teki itu. Dikatakan teka-teki dalam rumusan masalah yang ingin dikaji disebabkan masalah itu tentu ada jawabannya, dan siswa didorong untuk mencari jawaban yang tepat. Proses mencari jawaban itulah yang sangat penting dalam strategi inkuiri, oleh sebab itu melalui proses tersebut siswa akan memperoleh pengalaman yang sangat berharga sebagai upaya mengembangkan mental melalui proses berpikir.

c. Merumuskan Hipotesis

Hipotesis adalah jawaban sementara dari suatu permasalahan yang sedang dikaji. Sebagai jawaban sementara, hipotesis perlu diuji kebenarannya.

${ }^{17}$ Hamruni, Strategi dan Model..., 131.

${ }^{18}$ Hamruni, Strategi.., 138-141. Berbeda dengan Mulyono dalam bukunya Strategi Pembelajaran, memberikan 5 tahapan proses inkuiri, yaitu: (1) Merumuskan masalah, (2) Mengembangkan hipotesis, (3) Menguji jawaban tentatif, (4) Menarik kesimpulan, (5) Menerapkan kesimpulan dan generalisasi. Ngalimun juga memberikan tahapan proses inkuiri melalui 5 tahap namun dengan istilah yang sedikit berbeda, yaitu: (1) Penerimaan dan pendefinisian masalah, (2) pengembangan hipotesis, (3) pengumpulan data, (4) pengujian hipotesis, (5) penarikan kesimpulan sementara. Ngalimun, Strategi dan Model Pembelajaran, (Yogyakarta: Aswaja Pressindo, 2012), 36-37 
Perkiraan sebagai hipotesis bukan sembarang perkiraan, tetapi harus memiliki landasan berpikir yang kokoh, sehingga hipotesis yang dimunculkan itu bersifat rasional dan logis. Kemampuan berpikir logis itu sendiri akan sangat dipengaruhi oleh kedalaman wawasan yang dimiliki serta keluasan pengalaman. Dengan demikian, setiap individu yang kurang mempunyai wawasan akan sulit mengembangkan hipotesis yang rasional dan logis.

d. Mengumpulkan Data

Mengumpulkan data adalah aktivitas menjaring informasi yang dibutuhkan untuk menguji hipotesis yang diajukan. Dalam strategi pembelajaran inkuiri, mengumpulkan data merupakan proses mental yang sangat penting dalam pengembangan intelektual. Proses pengumpulan data bukan hanya memerlukan motivasi yang kuat dalam belajar, akan tetapi juga membutuhkan ketekunan dan kemampuan menggunakan potensi berpikirnya. Karena itu, tugas dan peran guru dalam tahapan ini adalah mengajukan pertanyaan-pertanyaan yang dapat mendorong siswa untuk berpikir mencari informasi yang dibutuhkan. Sering terjadi kemacetan berinkuiri adalah manakala siswa tidak apresiatif terhadap pokok permasalahan. Tidak apresiatif itu biasanya ditunjukkan oleh gejala-gejala tidak ada minat dalam belajar. Manakala guru menemukan gejala-gejala semacam ini, maka guru hendaknya secara terus-menerus memberikan dorongan kepada siswa untuk belajar melalui penyuguhan berbagai jenis pertanyaan secara merata kepada seluruh siswa sehingga mereka terangsang untuk berpikir.

\section{e. Menguji hipotesis}

Menguji hipotesis adalah proses menentukan jawaban yang dianggap diterima sesuai dengan data atau informasi yang diperoleh berdasarkan pengumpulan data. Dalam menguji hipotesis yang terpenting adalah mencari tingkat keyakinan siswa atas jawaban yang diberikan. Di samping itu, menguji hipotesis juga berarti mengembangkan kemampuan berpikir rasional. Artinya, kebenaran jawaban yang diberikan bukan hanya berdasarkan argumentasi, akan tetapi harus didukung oleh data yang ditemukan dan dapat dipertanggungjawabkan.

\section{f. Merumuskan kesimpulan}

Merumuskan kesimpulan adalah proses mendeskripsikan temuan yang diperoleh berdasarkan hasil pengujian hipotesis. Merumuskan kesimpulan merupakan "gongnya" dalam proses pembelajaran. Sering terjadi, karena banyaknya data yang diperoleh, menyebabkan kesimpulan yang dirumuskan 
tidak fokus pada masalah yang hendak dipecahkan. Karena itu, untuk mencapai kesimpulan yang akurat sebaiknya guru mampu menunjukkan pada siswa data mana yang relevan.

\section{g. Pendekatan-pendekatan dalam Inkuiri}

Pendekatan inkuiri terbagi menjadi tiga jenis berdasarkan besarnya intervensi guru terhadap siswa atau besarnya bimbingan yang diberikan oleh guru kepada siswanya. Ketiga jenis pendekatan inkuiri tersebut adalah: ${ }^{19}$

1) Inkuiri Terbimbing (Guided Inquiry Approach)

Pendekatan inkuiri terbimbing yaitu pendekatan inkuiri dimana guru membimbing siswa melakukan kegiatan dengan memberi pertanyaan awal dan mengarahkan pada suatu diskusi. Guru mempunyai peran aktif dalam menentukan permasalahan dan tahap-tahap pemecahannya. Pendekatan inkuiri terbimbing ini digunakan bagi siswa yang kurang berpengalaman belajar dengan pendekatan inkuiri.

Dengan pendekatan ini siswa belajar lebih beorientasi pada bimbingan dan petunjuk dari guru hingga siswa dapat memahami konsepkonsep pelajaran. Pada pendekatan ini siswa akan dihadapkan pada tugastugas yang relevan untuk diselesaikan baik melalui diskusi kelompok maupun secara individual agar mampu menyelesaikan masalah dan menarik suatu kesimpulan secara mandiri.

2) Inkuiri Bebas (Free Inquiry Approach)

Pada umumnya pendekatan ini digunakan bagi siswa yang telah berpengalaman belajar dengan pendekatan inkuiri. Karena dalam pendekatan inkuiri bebas ini menempatkan siswa seolah-olah bekerja seperti seorang ilmuwan. Siswa diberi kebebasan menentukan permasalahan untuk diselidiki, menemukan dan menyelesaikan masalah secara mandiri, merancang prosedur atau langkah-langkah yang diperlukan. Selama proses ini, bimbingan dari guru sangat sedikit diberikan atau bahkan tidak diberikan sama sekali.

Salah satu keuntungan belajar dengan metode ini adalah adanya kemungkinan siswa dalam memecahkan masalah open ended dan mempunyai alternatif pemecahan masalah lebih dari satu cara, karena tergantung bagaimana cara mereka mengkonstruksi jawabannya sendiri.

${ }^{19}$ Hamruni mengemukakan beberapa macam model-model pembelajaran Inkuiri dalam bukunya, yaitu: (1) Guide Inquiry, (2) Modified Inquiry, (3) Free Inquiry, (4) Inquiry Role Approach, (5) Invitation into Inquiry, (6) Pictorial Riddle, (7) Synectics Lesson, dan (8) Value Clarification. Lihat Hamruni, Strategi dan Model..., 144-146. 
Selain itu, ada kemungkinan siswa menemukan cara dan solusi yang baru atau belum pernah ditemukan oleh orang lain dari masalah yang diselidiki.

3) Inkuiri Bebas yang Dimodifikasikan (Modified Free Inquiry Approach)

Pendekatan ini merupakan kolaborasi atau modifikasi dari dua pendekatan inkuiri sebelumnya, yaitu: pendekatan inkuiri terbimbing dan pendekatan inkuiri bebas. Meskipun begitu permasalahan yang akan dijadikan topik untuk diselidiki tetap diberikan atau mempedomani acuan kurikulum yang telah ada. Artinya, dalam pendekatan ini siswa tidak dapat memilih atau menentukan masalah untuk diselidiki secara sendiri, namun siswa yang belajar dengan pendekatan ini menerima masalah dari gurunya untuk dipecahkan dan tetap memperoleh bimbingan. Namun bimbingan yang diberikan lebih sedikit dari Inkuiri terbimbing dan tidak terstruktur.

Dalam pendekatan inkuiri jenis ini guru membatasi memberi bimbingan, agar siswa berupaya terlebih dahulu secara mandiri, dengan harapan agar siswa dapat menemukan sendiri penyelesaiannya. Namun, apabila ada siswa yang tidak dapat menyelesaikan permasalahannya, maka bimbingan dapat diberikan secara tidak langsung dengan memberikan contoh-contoh yang relevan dengan permasalahan yang dihadapi, atau melalui diskusi dengan siswa dalam kelompok lain.

\section{Kelebihan Model Pembelajaran Inkuiri}

a. Menekankan kepada pengembangan aspek kognitif, afektif, dan psikomotor secara seimbang, sehingga pembelajaran melalui strategi ini dianggap lebih bermakna;

b. Memberikan kesempatan kepada siswa untuk belajar sesuai dengan gaya belajarnya;

c. Sesuai dengan perkembangan psikologi belajar modern yang menganggap belajar adalah proses perubahan tingkah laku lewat pengalaman;

d. Mampu melayani kebutuhan siswa yang memiliki kemampuan diatas rata, sehingga siswa yang memiliki kemampuan belajar bagus tidak akan terhambat oleh siswa yang lemah dalam belajar. 


\section{Kelemahan Model Pembelajaran Inkuiri}

a. Sulit mengontrol kegiatan dan keberhasilan siswa;

b. Tidak mudah mendesainnya, karena terbentur dengan kebiasaan siswa;

c. Terkadang dalam implementasinya memerlukan waktu yang panjang, sehingga guru sulit menyesuaikannya dengan waktu yang telah ditentukan;

d. Selama kriteria keberhasilan belajar ditentukan oleh kemampuan siswa menguasai materi pelajaran, maka strategi ini akan sulit diimplementasikan oleh setiap guru. ${ }^{20}$

\section{Kontribusi Terhadap Penguatan Kualitas Pembelajaran}

Penguatan merupakan salah satu bentuk respon baik verbal maupun non verbal yang diberikan guru terhadap tingkah laku siswa untuk memberikan umpan balik atas perbuatannya sebagai suatu dorongan atau koreksi dan memotivasi siswa yang lain untuk berbuat hal yang sama seperti siswa yang diberikan penguatan tadi. ${ }^{21}$ Penguatan diartikan dengan tingkah laku guru dalam merespon secara positif suatu tingkah laku tertentu siswa yang memungkinkan tingkah laku tersebut timbul kembali, dimaksudkan untuk mengganjar atau membesarkan hati siswa agar mereka lebih giat berpartisipasi dalam interaksi proses belajar mengajar. ${ }^{22}$

Penguatan kualitas pembelajaran merupakan suatu proses yang menekankan pada pemahaman-pemahaman yang seharusnya dilakukan dalam proses pembelajaran, demi tercapainya tujuan yang diinginkan seorang pendidik. Kualitas pembelajaran sekarang ini jauh seperti harapan-harapan yang tertuang dalam tujuan pendidikan secara universal. Proses pembelajaran yang masih berbasis kejar tayang, pembelajaran yang sebaiknya mengedepankan keaktifan siswa, serta proses transfer ilmu yang masih dalam tahap proses dan belum mencapai manfaat yang diharapkan menjadi fenomena yang sudah membudaya dari generasi ke generasi berikutnya. Hal itu tentu akan berakibat fatal apabila tidak segera dilakukan upaya-upaya pengembangan baik, model, strategi, ataupun metode pembelajaran dalam menciptakan iklim akademis sesuai dengan tujuan dan harapan bersama-sama.

${ }^{20}$ Hamruni, Strategi dan Model..., 143-144.

${ }^{21}$ Wina Sanjaya, Strategi Pembelajaran berorientasi Standar Proses Pendidikan, Jakarta: Kencana, 2009, hlm. 37

${ }^{22}$ Hasibuan, J.J, Proses Belajar Mengajar, Bandung: Remaja Rosdakarya, 2008, hlm. 58 
1. Tujuan Pemberian Penguatan

Pemberian penguatan dalam rangka meningkatkan kualitas pembelajaran bertujuan untuk :

a. Meningkatkan perhatian siswa dan membangkitkan motivasi siswa;

b. Memudahkan siswa belajar;

c. Mengontrol dan memodifikasi tingkah laku siswa serta mendorong munculnya perilaku yang positif;

d. Menumbuhkan rasa percaya diri pada siswa;

e. Memelihara iklim kelas yang kondusif. ${ }^{23}$

2. Jenis dan Prinsip Pemberian Penguatan

a. Penguatan Verbal

Penguatan ini paling mudah digunakan dalam kegiatan pembelajaran dalam bentuk komentar, pujian, dukungan, pengakuan, atau dorongan. Seperti kata bagus, luar biasa, atau tepat sekali. ${ }^{24}$

b. Penguatan Non Verbal

Merupakan penguatan yang dapat dilakukan menggunakan bahasa isyarat, seperti mimik muka dan gerakan badan, pemberian simbol atau benda, sentuhan, gerakan mendekati, kegiatan yang menyenangkan, dan penguatan tak penuh. ${ }^{25}$

Prinsip-prinsip dari penguatan dalam meningkatkan kualitas pembelajaran sendiri adalah: ${ }^{26}$

a. Kehangatan dan keantusiasan

Kehangatan dan keantusiasan dapat ditunjukkan dengan berbagai cara misalnya, dengan muka berseri disertai senyuman, suara riang penuh perhatian, atau sikap yang memberi kesan bahwa penguatan yang diberikan sungguhsungguh.

b. Kebermaknaan;

Penguatan yang diberikan oleh guru haruslah bermakna bagi siswa, yaitu membuat siswa memang merasa bahwa

${ }^{23}$ Udin Winata Putra. Dkk, Strategi Belajar Mengajar, Jakarta: Universitas Terbuka, 2004, hlm. 30

${ }^{24}$ Ibid..,hlm. 33

${ }^{25}$ Ibid..,hlm 33

${ }^{26}$ Ibid..,35 
penampilan atau tindakannya patut diberikan penguatan, sehingga siswa terdorong untuk meningkatkan penampilannya.

c. Menghindari penggunaan respon negatif;

Menghindari seperti kata-kata kasar, cercaan, hukuman, atau ejekan dari guru yang merupakan senjata ampuh untuk menghancurkan iklim kelas yang kondusif maupun kepribadian siswa sendiri. Oleh karena itu guru hendaknya menghindari segala jenis respon negative tersebut.

\section{SIMPULAN}

Model pembelajaran Discovery-Inkuiri merupakan salah satu dari beberapa model pembelajaran yang berhasil dikembangkan dalam menghasilkan kualitas pembelajaran yang kreatif dan menyenangkan. Model pembelajaran yang menekankan pada proses berpikir kritis dan analitis untuk mencari dan menemukan sendiri jawaban dari pertanyan-pertanyaan dari permasalahan yang dimunculkan melalui tanya jawab antara guru dan siswa. Model pembelajaran ini memiliki pandangan bahwa kemunculan rasa ingin tahu yang tinggi merupakan kodrati manusia sebagai makhluk ciptaan Tuhan yang ingin mengetahui kebenarannya, khususnya dalam proses pembelajaran.

Penguatan kualitas pembelajaran sendiri mengarah kepada berbagai proses pembelajaran yang terjadi selama ini belum mencapai klimaks sesuai yang diharapkan. Oleh karena itu, diperlukan model pembelajaran yang memiliki tujuan yang sama dengan ruh pendidikan dalam menciptakan kualitas-kualitas pembelajaran yang mampu menghasilkan output peserta didik sesuai dengan kriteria perkembangan zaman. 


\section{DAFTAR PUSTAKA}

B. Gilbert Christine and John T. Gillespie, The New Book Of Knowledge, Grolier: Incorporated Danbury. Conn. Tth.

Bachri Syaiful, 2003, Strategi Belajar Mengajar, Jakarta: Rineka Cipta.

Departermen Pendidikan Nasional, 2004, Teori-teori Belajar, Yogyakarta: Bahan Pelatihan Terintegrasi Berbasis Kompetensi Guru SMP.

Hamruni, 2009, Strategi dan Model-Model Pembelajaran Aktif yang Menyenangkan", Yogyakarta: Fakultas Tarbiyah UIN Sunan Kalijaga Yogyakarta.

Hasibuan, 2008, J.J, Proses Belajar Mengajar, Bandung: Remaja Rosdakarya.

Mulyono, 2011, Strategi Pembelajaran; Menuju Efektivitas Pembelajaran di Abad Global, Malang, UIN-Maliki Press.

Ngalimun, 2012, Strategi dan Model Pembelajaran, Yogyakarta: Aswaja Pressindo.

Rostiyah, 2008, Strategi Belajar Mengajar,cet-7, Jakarta: Rineka Cipta.

Ruseffendi, 2006, Metode Penelitian, Yogyakarta: Pustaka Pelajar.

Shoimin Aris, 2016, 68 Model Pembelajaran Inovatif dalam Kurikulum 2013, Yogyakarta: Ar-Ruzz Media.

Soegarda Poerbakawatja, 1976, Ensiklopedi Pendidikan, Jakarta : Gunung Agung,.

Suprijono Agus, 2013, Cooperative Learning: Teori dan Aplikasi PAIKEM, Yogyakarta: Pustaka Pelajar.

Suryobroto, 2002, Proses Belajar Mengajar, Bandung: Remaja Rosdakarya.

Tabrani Rusyan dkk., 1994, Pendekatan dalam Proses Belajar Mengajar, Bandung: PT. Remaja Rosdakarya. 
170 | AR-RIAYAH : Jurnal Pendidikan Dasar vol.1, no. 2, 2017

Undang-Undang RI No. 20 Tahun 2003, 2003, Sistem Pendidikan Nasional, Jakarta: Citra Umbara.

Usman, 1993, Upaya Mengoptimalisasi Kegiatan Belajar Mengajar. Bandung: Remaja Rosda Karya.

Udin Winata Putra. dkk, 2004, Strategi Belajar Mengajar, Jakarta: Universitas Terbuka.

Wina Sanjaya, 2009, Strategi Pembelajaran berorientasi Standar Proses Pendidikan, Jakarta: Kencana. 